\title{
Structural and Functional Relations between the Connective Tissue and Epithelium of Enamel Organ and their Role during Enamel Maturation
}

Anas F Mahdee ( $\sim$ a.f.mahde@codental.uobaghdad.edu.iq )

University of Baghdad College of Dentistry https://orcid.org/0000-0001-9789-6840

Ahmed H Ali

Department of Restorative and Aesthetic Dentistry, College of Dentistry, University of Baghdad James I Gillespie

Urology and Urological Rehabilitation, Antwerp University

\section{Original Paper}

Keywords: Enamel organ, enamel maturation, interstitial cells, ameloblast, papillary layer, connective tissue

Posted Date: February 5th, 2021

DOI: https://doi.org/10.21203/rs.3.rs-157576/v1

License: (c) (i) This work is licensed under a Creative Commons Attribution 4.0 International License. Read Full License 


\section{Abstract}

The morphological and possible functional interactions between the connective tissue and epithelial elements of enamel organ were examined during the maturation phase, using immunohistochemical techniques. Decalcified mandibular sections $(10 \mu \mathrm{m})$ including incisors from Wistar rats ages 10-12 weeks were used. Sections were incubated with one or two primary antibodies targeting cell cytoskeleton (vimentin, a-actin, a-tubulin), dendritic marker (OX6), gap junctions (cx-43), enzymes (nitric-oxide synthase (nos1) and cyclooxygenase (cox1)), and ion transporters $\left(\mathrm{Na}^{+} / \mathrm{H}^{+}\right.$exchanger (NHE1) and $\mathrm{Na}^{+} / \mathrm{Ca}^{2+}$ exchanger (NCX)) for $24 \mathrm{~h}$, before incubation with the appropriate conjugated fluorescent secondary antibodies. Sections were then examined by fluorescence microscopy. Haematoxylin-eosin slides were also employed. Cellular heterogeneity and morphological modulations were identified within the epithelial and connective tissue elements of the enamel organ suggesting complex cellular interactions and indicating the use of enamel organ term to represent all these regions. Also, some ion transportation activity, and nos 1 and cox 1 signalling pathways have been identified, indicating intercellular communication between these regions. A hypothesis was suggested, to explain the morphological modulation of ameloblasts and papillary cells during enamel maturation aimed to increase the transporting membrane surface area to accomplish faster and bulker ion transportation to achieve controlled $\mathrm{pH}$ and to direct $\mathrm{Ca}^{2+}$ towards enamel. Connective tissue covering epithelial cells of the enamel organ showed morphological and physiological interaction during enamel maturation, suggesting new functional concepts.

\section{Introduction}

Amelogenesis is a complex physiological process that occurs within the enamel organ to underpin the formation of enamel. it has been suggested that the enamel organ consist of avascular epithelial layers where the inner most stratified layer, ameloblasts, are responsible for the secretion of an initial noncollagenous protein matrix (Lacruz et al. 2017). Followed that, secretion of large quantities of calcium and phosphate ions, and formation of unique architecture of hydroxyapatite crystals forming rods and interrods (Cui and Ge 2007; Smith and Nanci 1995). The vascular supply has been described and located within the connective tissue overlying the enamel organ epithelia (El-Agroudi et al. 1998). However, the specific processes that control the transport and secretion of the organic and inorganic material from the vascular connective tissue region to the avascular epithelium region of enamel organ toward enamel is poorly understood.

Throughout the period of enamel formation, the ameloblast (Am) cells undergo substantial structural remodelling from a short columnar in the early differentiation stage, to tall, well developed cells with apical processes (Tomes' process) during secretory phase. At this stage the cells are described as being in the secretory phase. This is followed by a loss of the Tomes' processes, shortening and widening of ameloblasts in preparation for mineralisation of enamel matrix, the maturation phase (Smith and Nanci 1995). Within the latter phase, the ameloblasts undergo cyclic morphological remodelling from ruffledended to smooth-ended ameloblasts (Josephsen et al. 2010). The tight junctions between ameloblasts 
are also remodelled between the apical border in the ruffle-ended to the opposite basal border in the smooth-ended ameloblasts (Josephsen and Fejerskov 1977). This is associated with cyclic changes in the $\mathrm{pH}$ of the enamel surface from acidic $(\mathrm{pH}=6)$ during ruffled-ended ameloblasts to neutral $(\mathrm{pH}=7)$ during the smooth ameloblasts (Sasaki et al. 1991). However, the control for these cellular remodelling process and cyclic ions secretion has not yet been identified.

The outer epithelial layers of the enamel organ also undergoes changes as the enamel organ develops. In the initial secretory phase the epithelium consists of different layers; stratum intermedium, stellate reticulum. In the maturation phase the epithelium expands and the cells appear more homogeneous. These papillary cells are rich in mitochondria and form highly folded series of tightly packed ridges (Kallenbach 1967). Between these ridges blood vessels are seen to descend from the connective tissue layer forming complex vascular bed (El-Agroudi et al. 1998). An addition cell type, described as dendritic cells, have also been seen within the papillary folds, but their functional role is still unknown (Nishikawa and Sasaki 1999; Nishikawa and Sasaki 2000).

The aim of this study was to use immunofluorescent techniques to determine the cellular location of functional ion transporting systems within the complex structures of the enamel organ and connective tissue layer. Due to this intimate relations, the term, enamel organ, was used within the present study to represent both the epithelium and connective tissue surrounding.

\section{Materials And Methods}

Twenty male Wistar rats, $10-12$ weeks ages $(350-400 \mathrm{~g})$ were used in this study. Animals were killed within $\mathrm{CO}_{2}$ chamber, according to the schedule 1, UK Home Office guidelines, before dissecting the mandibles and dividing them into two. Each half mandible was fixed by immersion in $4 \%$ paraformaldehyde in phosphate buffer saline for $24 \mathrm{~h}$ at $4^{\circ} \mathrm{C}$. The specimens then were washed thoroughly with distilled water, demineralised, frozen into blocks, and sectioned into sagittal sections (10 $\mu \mathrm{m}$ thickness) according to the procedure described previously (Mahdee et al. 2016). Two slides from each specimen were further fixed by immersion into $40 \%$ formal calcium for one hour before staining with haematoxylin and eosin stain. Slides were processed by immunohistochemistry staining according to the procedure described in Mahdee et al. (2016). In brief, the method of staining included single or double labelling with antibodies targeting cell structure or functional proteins (details for those antibodies illustrated in Table 1). Slides were incubated with primary antibodies for $24 \mathrm{~h}$ at $4^{\circ} \mathrm{C}$ before washing and staining with the appropriate conjugated secondary fluorescence antibody (one hour at room temperature), before washing and embedding in Vectashield hard set mounting medium with dapi (Vector Laboratories Inc, Burlingame, USA). Negative control slides were prepared: (i) by using the appropriate blocking peptide, specific for the antibodies used and employing isotope controls. These negative controls staining including Human alpha smooth muscle actin blocking peptide (Abcam cat\# ab 211918, UK) specifically manufacted for the a-actin used in this study. Additionally, rabbit IgG monoclonal (EPR25A) isotype control (1:500 Abcam cat\# ab172730, UK) and normal mouse IgG1 (1:500 Santa Cruz 
Biotechnology cat\# sc-3877 UK) were also employed. (ii) by using the secondary fluorescent antibodies without the tissue specific primary markers (Mahdee et al. 2018).

Eighty slides were examined for each stain to validate the staining patterns for each antibody and to confirm consistency and accuracy of the staining procedure. Slides were examined on an Olympus BX61 microscope (Olympus Corporation, Tokyo Japan) and images were captured with a microscope-mounted Olympus XM10 monochrome camera. Images were processed and analysed using ImageJ software (Java- based image processing program- National Institute of Health (USA)).

\section{Results}

All of the sections used in this study were taken from demineralised sagittal sections of the rat mandibular incisors exploring the maturation stage of enamel formation within the enamel organ. (Fig. 1) illustrates the major components and cell types within the enamel organ at this stage. The ameloblasts (Am) appear as a layer of columnar cells devoid of apical processes (Tomes' processes). The adjacent epithelial layer, the papillary layer (PL), lying above the ameloblasts is highly folded forming ridges within the organ. Above the papillary layer is a region of connective tissue (CT) within which there is a dense infiltration of blood vessels (arterioles and venules). Capillaries containing red blood cells can be seen to lie between the folds of the papillary region that presumably arise from vessels in the connective tissue layer. The connective tissue of the enamel organ is divided within the current study depending on the microvasculature bed distribution. The first or deep region (* in Fig. 1a) appears as a dense connective tissue with capillaries which are deeply integrated toward the adjacent papillary layer $(P L)$ to be closer to the ameloblasts, about one papillary cell thickness apart. The papillary layer from the other side projected toward the connective tissue in forms of long ridges. The connective tissue cells within this region arranged above the papillary ridges then extended interstitially between the capillaries and papillary ridges. These cells are termed as interstitial cells within the present study. The second region composed of loose connective tissue containing the arterioles, then large flattened vessels (venules) run closer to the alveolar bone. (Fig. 1b) shows the distribution of immuno-reactivity to a-smooth muscle actin (a-actin) within the enamel organ. Immuno-reactivity is seen within the wall of the arterioles and venules in the connective layer, within the papillary cells and strongly on the basal margins of the smooth-ended ameloblasts or the distal border in ruffle-ended ameloblasts (see Fig. 5, d and c respectively). It is noteworthy that no a-actin can be detected in the blood vessels or cells lying within the folds of the papillary cell layer.

Cells within the connective tissue layer are readily identified using the marker for intermediate filaments, vimentin (vim) (Fig. 2 a). In addition, vimentin positive cells can be identified within the papillary folds and over the papillary ridges (Fig 2 b). Immuno-reactivity to a dendritic cell marker (OX6) is illustrated in (Fig. 2 c), and shows the presence of dendritic cells deep within the folds of the papillary layer and also associated with the arterioles and venules of the connective tissue layer. 
Immuno-reactivity to the cytoskeleton component a-tubulin (a-tub) reveals that the cells of the connective tissue layer and cells within the papillary folds are immune-positive. This is a similar distribution to vimentin. Thus, in the spaces between the papillary folds there is a complex arrangement of different cell types, capillaries, vimentin and tubulin positive cells and dendritic cells. The functional interactions between these different cellular components remains unknown.

In order to gain some insight into possible functional interactions, the distribution putative cell signalling and functional elements was explored (Fig. 4 and 5). Dense immuno-labelling with an antibody to nitric oxide (nos1) is apparent within ameloblasts and with lesser intensity within papillary cells. No immunoreactivity was detected in the cells of the connective tissue layer or within the papillary folds.

Prostaglandin signalling cells, expressing cyclooxygenase-1 (cox1), were only detected within the papillary folds (Fig. 4). These cox1 positive cells have a circular or oval shape, appear closer to or within the capillaries.

Immuno-reactivity to functional ion transporter NaK-ATPase is strongly detected within the papillary cells (Fig. 5 a). In contrast, only low levels of expression were seen within the ruffled or smooth-ended ameloblasts. Similarly, the papillary cells show higher immuno-labelling with gap junctions' antibody [connexion-43 (cx43)] than the ameloblasts (Fig. 5 b). The cx43 appear as large punctuates or granules between the papillary cells themselves and between them and the ameloblasts. Within the later cell layer, the cx43 appear as smaller granules on the lateral membranes between ameloblasts in their different types (ruffled and smooth-ended).

Immuno-reactivity to sodium-hydrogen exchanger (NHE-1) can be detected but this appears to be different between ruffled and smooth border ameloblasts (Fig. 5 e and $f$ respectively). NHE-1 immunoreactivity is particularly strong within the connective tissue cells between the papillary folds in both the ruffled and smooth ameloblast phases. NHE-1 staining in the ameloblasts is present but low in the ruffled ameloblasts and more strongly expressed in the smooth phase especially within the lateral cell membrane.

The expression of a further ion transporter, the sodium-calcium exchanger (NCX), was employed (Fig. 6). It appeared to be similar within the smooth and ruffled ended phases and expressed within the different cellular compartment of the enamel organ. The highest immuno-reactivity of NCX is apparent within only a portion of the ameloblasts, dendritic cells and a population of cells lying on the papillary ridges (Fig. 6 b).

No specific tissue labelling has been observed within the negative control sections.

\section{Discussion}

All living tissues are basically composed of several types of cells which are developmentally, spatially, and physiologically integrated into a unit called organ. Several organs are available within a developed tooth, originated from ectodermal and mesenchymal compartment to generate its structural framework 
by the function of ameloblast and odontoblast cells (Krivanek et al. 2017). However, the real story is beyond this simplified scene. There are many types of cells within the pulp and enamel organ which are jointly participate and interact to perform their goals. The enamel forming cells which has been in the focus of many literatures for several decades are only the ameloblasts and the outer epithelial cells of the enamel organ (Lacruz et al. 2017; Smith and Nanci 1995), although there are other cells including dendritic cells (Nishikawa and Sasaki 2000), and the outer connective tissue which have strong spatial relationships with these epithelial cells. Additionally, the vascular source required for the viability and function of the epithelial part is located within the wrapping connective tissue which may confirm the functional integration between these different cells. Therefore, the present study used the term enamel organ for the whole cells including the epithelial and connective tissue surrounding and employed rat mandibular incisor teeth to investigate the structural and functional relationships between these cells during the process of enamel maturation. Since the rat mandibular incisor is a continuous growing tooth, it offers good model in studying the whole sequences of amelogenesis (Warshawsky and Smith 1974) within proper size and easily dissected tooth sample (Mahdee et al. 2018).

The intimate integration between the epithelial and the connective tissue of the enamel organ was clearly illustrated within the current study through the spatial relationship between the capillaries network and the papillary ridges. A highly organised microvasculature has been previously reported to be engaging within enamel organ, which showed an interruption at the cementoenamel junction on the mesial and distal sides of the enamel organ along the developing rat incisor (El-Agroudi et al. 1998). Therefore, the connective tissue, or what was previously called periodontal tissue, on the labial side of the rat incisor where the enamel is only present is different in its structure and microvasculature than the other sides of the tooth which have no enamel (Sasaki et al. 1984). Additionally, larger arterioles have been recognised in the current study above the papillary ridges through a-actin immuno-labelling for their muscular walls, and large sinusoid veins at the end of connective tissue region closer to the alveolar bone. This is in agreement with El-Agroudi et al. (1998), who classified the microvasculature bed of the enamel organ into deep, intermediate and outer layers.

According to the finding of the current study the connective tissue of enamel organ was composed of cells that were mainly immuno-labelled with vimentin and a-tubulin. While, the epithelial cells were immunoreactive to a-actin. These markers have been identified within the odontoblast and other pulp cells (Mahdee et al. 2016). In addition, the dendritic cells were also illustrated within the papillary layer that were immunolabelled with 0X6 marker (see Fig. 7 a). The heterogeneity among these cells of the enamel organ could reflect its complexity and the possible complementary rule during enamel maturation process. Furthermore, the morphological characteristics of the connective tissue cells showed regional differences especially through cells in close vicinity to the papillary cells. This may suggest a functional relation between these cells and the adjacent papillary cells. Among this cellular complexity, only very few were found in the literature about the connective tissue cells of the enamel organ with an unknown role during amelogenesis (Krivanek et al. 2017; Reith 1959). 
Another obvious physiological change within the current study (see Fig. 7 b) was the long papillary ridges with several capillaries incorporation along the inter-papillary region. These ridges can be estimated to be 2-4 the size of stellate reticulum layer projections during the secretory stage (El-Agroudi et al. 1998). This means that the surface area of the transporting membrane between epithelium and connective tissue has been totally 2-4 times larger during maturation stage. Additionally larger number of capillaries were shown to be incorporated within the papillary ridges with deeper invagination between them to be closer to ameloblast cells. These capillaries were reported to have very thin endothelium with numerous fenestrations facing enamel (Sasaki et al. 1984). All these can help to increase the rate of ion transportation from capillaries to be directed toward mineralising enamel.

Another important observation in this study is the spatial relationship between the dendritic cells and the capillaries. Most of these cells were observed in close vicinity to the capillaries and sending their cellular processes toward them. There were different studies reported the presence of dendritic cells within the epithelial part of the enamel organ but their function is not yet obvious (Nishikawa and Sasaki 2000). Although, their possible role in the engulfment process of the eliminated ameloginin enamel matrix material has been suggested (Nishikawa and Sasaki 1999), their immunological function as antigen presenting cells has to be taken in consideration (Nishikawa and Sasaki 2000). Moreover, these cells have been labelled with NCX (Fig $7 \mathrm{c}$ ) within the current study. This possibly reflect a signalling process within these cells directing their response into different stimulus (Shumilina et al. 2011). However, further studies are required to identify such stimulus.

The current study has also identified a repetitive change in the expression of a-actin antibody between the distal borders of the ruffle-ended ameloblasts to the basal membrane of the smooth-ended ameloblasts (see Fig. 7 b). This could confirm the cyclic modulation process of the ameloblast cells where the position of the tight junctional epithelium change from the apical border during ruffle-ended ameloblasts to the basal membrane during the smooth-ended ameloblasts (Bronckers 2017). This could offer more surface area of the ion exchanging membrane during the smooth-ended ameloblasts allowing all lateral and apical cellular membranes to achieve active ion transporting process. The NHE immunoreactivity also showed similar cyclic expression within different ameloblast phases that my cope with the suggested phenomena. The increase surface area within smooth ameloblast phase could add more power to the pH controlling process within enamel to change it from 6.2 during ruffled to 7.2 during smooth ameloblasts phases (Bronckers 2017; Josephsen et al. 2010). In addition, the apparent expression of NaK-ATPase within the papillary cells could be one of the major cellular function to produce this role through making electrochemical $\mathrm{Na}^{+}$gradient to maintain negative cell potential of the ameloblasts during their different modulation stages (Josephsen et al. 2010; Lacruz et al. 2013). This is supported by cytosol coupling through the presence of gap junctions between papillary cells and ameloblasts (Al-Ansari et al. 2018). All these may support unidirectional ion pumping toward enamel.

Nitric oxide examined within this study was neuronal type, produced by nNOS (nos1). Nitric oxide is a neurotransmitter and signalling molecules which has central and peripheral function. Centrally, it involves in memory, learning and controlling of blood pressure, whilst peripherally it helps to reduce vascular tone 
causing vasodilation by its effect on the smooth muscles (Förstermann and Sessa 2012). The presence of nos 1 has been previously demonstrated within ameloblasts during all stages of enamel formation and with less intensity within papillary layer during enamel maturation (Mahdee et al. 2017). This could indicate the role of ameloblasts and the papillary cells in controlling vascular tone within the covering connective tissue. Also the presence of nos within cells achieving continuous morphological and functional modulations could suggest the role of this neurotransmitter within this process through autocrine or paracrine signalling pathways. On the other hand, cox 1 immunoreactivity has been identified within some interstitial cells between and covering papillary ridges. The relation between nitric oxide and prostaglandin signalling pathways has been identified within different organs (Sorokin 2016) including the pulp (Alhelal 2016). This may indicate cellular cross talking between the epithelium and connective tissue of the enamel organ, however the purpose for such cellular interactions need further investigations.

Although the role of enamel epithelium in transporting systematic $\mathrm{Ca}^{2+}$ directly to enamel has been identified, the mechanisms behind this ion transportation is far from clear (Nurbaeva et al. 2017). The dominant paradigm for $\mathrm{Ca}^{2+}$ transportation has been agreed to be transcellular route (Bawden 1989; Nurbaeva et al. 2017), especially through studies showing the lack for diffusion of horseradish peroxidase and lanthanum across intercellualr junctions between ameloblasts (Takano 1995; Takano and Crenshaw 1980). According to the results of the present study, high intensity of NCX1 immunolabelling was identified within the ameloblasts during maturation stage. This is in agreement with Okumura et al. (2010) who first reported the present of NCX1 and NCX3 within the mature ameloblasts. However, they claimed the localization of this ion transporter on the apical membrane, whilst the current study has shown in clear and highly magnified images that NCX1 was active within the whole ameloblast cell including apical, middle and basal regions. Regarding the function of NCX, it is a bidirectional electronic transporter exchanging one $\mathrm{Ca}^{2+}$ for three $\mathrm{Na}^{+}$ions. Therefore, it depends on the membrane concentration potentials for $\mathrm{Na}^{+}$and $\mathrm{Ca}^{2+}$ ions to accomplish influx or efflux of $\mathrm{Ca}^{2+}$ (Nurbaeva et al. 2017). As mentioned previously, due to the intensive activity of NaK-ATPase within the papillary cells, this increases the $\mathrm{Na}^{+}$concentration within the extracellular fluid between cells (See Fig. $7 \mathrm{c}$ ). This may activate the NCX on the basal part of the ameloblasts to intrude $\mathrm{Ca}^{2+}$ inside the ameloblasts. There are several reported scenarios to buffer the intracellular $\mathrm{Ca}^{2+}\left[\mathrm{Ca}^{2+}\right]$ i within ameloblasts (Bronckers 2017; Nurbaeva et al. 2017). These may include calcium binding proteins (parvalbumin, calbindin, calretinin, calmodulin etc.) which are able to bind and transport $\mathrm{Ca}^{2+}$ from basal to apical direction without raising $\left[\mathrm{Ca}^{2+}\right]$ i (Davideau et al. 1993; Kördel et al. 1993). Another intracellular regulating method that has been presented within ameloblasts is ATPase pumps including; sarcoplasmic reticulum $\mathrm{Ca}^{2+}{ }^{2}$-ATPase (SERCA) to pump cytosolic [ $\left.\mathrm{Ca}^{2+}\right]$ i into the endoplasmic reticulum, and plasma membrane $\mathrm{Ca}^{2+}$-ATPase (PMCA)] as active $\mathrm{Ca}^{2+}$ pumping procedures toward enamel (Franklin et al. 2001; Zaki et al. 1996). Also passive ion exchangers [NCX and $\mathrm{K}^{+}$dependant $\mathrm{Na}^{+} / \mathrm{Ca}^{2+}$ exchanger (NCKX)] are also present, which passively efflux $\mathrm{Ca}^{2+}$ toward enamel (Hu et al. 2012; Okumura et al. 2010). This can explain the presence of NCX immunoreactivity within the apical region of ameloblasts in the present study. 
Another intense immunoreactivity of NCX has been recorded within the interstitial cells of the connective tissue. These cells were identified in close vicinity to capillaries, the main source of ions to be transported toward the epithelial region of enamel organ. There are two possibilities for this NCX immunoreactivity; either intrusion of $\mathrm{Ca}^{2+}$ into these cells or extrusion of $\mathrm{Ca}^{2+}$ out of these cells. If the first possibility is considered, $\mathrm{Ca}^{2+}$ influx may have a broad versatility within cellular signalling processes (Berridge et al. 2003) that need to be identified in further studies. However, if the second possibility is treated, $\mathrm{Ca}^{2+} \mathrm{efflux}^{2}$ will increase extracellular $\mathrm{Ca}^{2+}$ concentration which may facilitate $\mathrm{Ca}^{2+}$ diffusion into the epithelial part of enamel organ. All these possibilities are raising questions about the exact role of these interstitial cells during the process of amelogenesis.

In conclusions a new concept has been suggested to include all epithelium, dendritic cells and connective tissue compartment within the enamel organ because of the spatial and functional intermingling of these cells. Some new ideas about the possible physiology behind cellular morphological changes during enamel maturation phase within the papillary layer and ameloblasts have been suggested. These cellular morphological changes could play a pivotal role in the process of ion transportation to control $\mathrm{pH}$ and $\mathrm{Ca}^{2+}$ movement during this stage of enamel formation.

\section{Declarations}

Funding No funding was received for conducting this study.

Conflict of Interest/ Competing interests The authors have no conflicts of interest to declare that are relevant to the content of this article.

Availability of data and material All data and materials have been listed within the manuscript.

Code Availability not applicable.

Author contribution All authors contributed to the study conception and design. Material preparation, data collection and analysis were performed by [Anas F Mahdee], and [James I Gillespie]. The first draft of the manuscript was written by [Anas F Mahdee] and all authors commented on previous versions of the manuscript. All authors read and approved the final manuscript.

Ethical approval The animal work was performed according to the schedule 1, UK Home Office guidelines, within the facilities of the Oral Biology Department in the Institute of Cellular Medicine, Newcastle University. All applicable international, national, and/or institutional guidelines for the care and use of animals were followed.

Consent to participate For this type of study, formal consent is not required.

Consent for publication For this manuscript, consent for publication is not required. 
Acknowledgement The authors would like to thank Dr. John M. Whitworth (Professor of Endodontology at the School of Dental Sciences/ Newcastle University) for his support of this work.

\section{References}

Al-Ansari S et al. (2018) The importance of connexin 43 in enamel development and mineralization Front Physiol 9:750

Alhelal A (2016) Physiological and molecular responses in the pulp associated with early inflammatory process. PhD thesis submitted to Newcastle University

Bawden JW (1989) Calcium transport during mineralization The Anatomical Record 224:226-233

Berridge MJ, Bootman MD, Roderick HL (2003) Calcium signalling: dynamics, homeostasis and remodelling Nature reviews Molecular cell biology 4:517-529

Bronckers A (2017) Ion transport by ameloblasts during amelogenesis J Dent Res 96:243-253

Cui FZ, Ge J (2007) New observations of the hierarchical structure of human enamel, from nanoscale to microscale J Tissue Eng Regen Med 1:185-191

Davideau J, Celio M, Hotton D, Berdal A (1993) Developmental pattern and subcellular localization of parvalbumin in the rat tooth germ Arch Oral Biol 38:707-715

El-Agroudi MA, Selliseth NJ, Selvig KA (1998) Microvascular system of the rat incisor enamel organ. A scanning electron microscopic study of vascular corrosion casts Eur J Oral Sci 106:1013-1021

Förstermann U, Sessa WC (2012) Nitric oxide synthases: regulation and function Eur Heart J 33:829-837

Franklin IK, Winz RA, Hubbard MJ (2001) Endoplasmic reticulum Ca2+-ATPase pump is up-regulated in calcium-transporting dental enamel cells: a non-housekeeping role for SERCA2b Biochem J 358:217-224

Hu P, Lacruz RS, Smith CE, Smith SM, Kurtz I, Paine ML (2012) Expression of the sodium/calcium/potassium exchanger, NCKX4, in ameloblasts Cells Tissues Organs 196:501-509

Josephsen K, Fejerskov $\mathrm{O}$ (1977) Ameloblast modulation in the maturation zone of the rat incisor enamel organ. A light and electron microscopic study J Anat 124:45

Josephsen K, Takano Y, Frische S, Praetorius J, Nielsen S, Aoba T, Fejerskov O (2010) Ion transporters in secretory and cyclically modulating ameloblasts: a new hypothesis for cellular control of preeruptive enamel maturation Am J Physiol Cell Ph 299:C1299-C1307

Kallenbach E (1967) Cell architecture in the papillary layer of rat incisor enamel organ at the stage of enamel maturation The Anatomical Record 157:683-697 
Kördel J, Skelton NJ, Akke M, Chazin WJ (1993) High-resolution solution structure of calcium-loaded calbindin D9k J Mol Biol 231:711-734

Krivanek J, Adameyko I, Fried K (2017) Heterogeneity and developmental connections between cell types inhabiting teeth Front Physiol 8:376

Lacruz RS, Habelitz S, Wright JT, Paine ML (2017) Dental enamel formation and implications for oral health and disease Physiol Rev 97:939-993

Lacruz RS, Smith CE, Kurtz I, Hubbard MJ, Paine ML (2013) New paradigms on the transport functions of maturation-stage ameloblasts J Dent Res 92:122-129 doi:10.1177/0022034512470954

Mahdee A, Alhelal A, Eastham J, Whitworth J, Gillespie J (2016) Complex cellular responses to tooth wear in rodent molar Archives of Oral Biology 61:106-114

Mahdee A, Eastham J, Whitworth J, Gillespie J (2018) Evidence for programmed odontoblast process retraction after dentine exposure in the rat incisor Arch Oral Biol 85:130-141

Mahdee AF, Alhelal AG, Whitworth J, Eastham J, Gillespie J (2017) Evidence For Complex Physiological Processes In The Enamel Organ of The Rodent Mandibular Incisor Throughout Amelogenesis Medical Journal of Babylon 14:68-82

Nishikawa S, Sasaki F (1999) Internalization of amelogenin by dendritic cells of the papillary layer during transition and early maturation stages Histochem Cell Biol 112:301-305

Nishikawa S, Sasaki F (2000) Detection of immature dendritic cells in the enamel organ of rat incisors by using anti-cystatin C and anti-MHC class II immunocytochemistry J Histochem Cytochem 48:1243-1255

Nurbaeva MK, Eckstein M, Feske S, Lacruz RS (2017) Ca2+ transport and signalling in enamel cells The Journal of physiology 595:3015-3039

Okumura R, Shibukawa Y, Muramatsu T, Hashimoto S, Nakagawa K-I, Tazaki M, Shimono M (2010) Sodium-calcium exchangers in rat ameloblasts J Pharmacol Sci 112:223-230

Reith EJ (1959) The enamel organ of the rat's incisor, its histology and pigment Anat Rec 133:75-89

Sasaki S, Takagi T, Suzuki M (1991) Cyclical changes in pH in bovine developing enamel as sequential bands Arch Oral Biol 36:227-231

Sasaki T, Tominaga H, Higashi S (1984) Microvascular architecture of the enamel organ in the rat-incisor maturation zone. Scanning and transmission electron microscopic studies Cells Tissues Organs 118:205213

Shumilina $\mathrm{E}$, Huber SM, Lang F (2011) Ca2+ signaling in the regulation of dendritic cell functions American Journal of Physiology-Cell Physiology 300:C1205-C1214

Page 11/23 
Smith CE, Nanci A (1995) Overview of morphological changes in enamel organ cells associated with major events in amelogenesis Int J Dev Biol 39:153-161

Sorokin A (2016) Nitric oxide synthase and cyclooxygenase pathways: A complex interplay in cellular signaling Curr Med Chem 23:2559-2578

Takano Y (1995) Enamel mineralization and the role of ameloblasts in calcium transport Connect Tissue Res 33:127-137

Takano Y, Crenshaw M (1980) The penetration of intravascularly perfused lanthanum into the ameloblast layer of developing rat molar teeth Arch Oral Biol 25:505-511

Warshawsky H, Smith C (1974) Morphological classification of rat incisor ameloblasts The Anatomical Record 179:423-445

Zaki A, Hand A, Mednieks M, Eisenmann D, Borke J (1996) Quantitative immunocytochemistry of Ca2+Mg2+ ATPase in ameloblasts associated with enamel secretion and maturation in the rat incisor Adv Dent Res 10:245-251

\section{Table}

Table 1 Primary antibody markers used in this study

\begin{tabular}{|c|c|c|}
\hline Abb. & Antibody (conc.) (purpose for use) & Supplier \\
\hline vim & $\begin{array}{l}\text { mouse monoclonal anti-vimentin (1:5000) (cell structural } \\
\text { antibody to detect intermediate filaments) }\end{array}$ & $\begin{array}{l}\text { BioGenex, Launch } \\
\text { Diagnostics cat\# } \\
\text { MU074-UC, UK }\end{array}$ \\
\hline$\alpha$-actin & $\begin{array}{l}\text { rabbit monoclonal anti- } \alpha \text { smooth muscle actin }(1: 200) \\
\text { (cell structural antibody to detect microfilaments) }\end{array}$ & $\begin{array}{l}\text { Abcam cat\# ab32575, } \\
\text { UK }\end{array}$ \\
\hline$\alpha$-tub & $\begin{array}{l}\text { rabbit polyclonal anti- } \alpha \text { tubulin }(1: 1000) \text { (cell structural } \\
\text { antibody to detect microtubules) }\end{array}$ & $\begin{array}{l}\text { GeneTex, cat\# } \\
\text { GTX102078, USA }\end{array}$ \\
\hline OX6 & $\begin{array}{l}\text { mouse monoclonal anti-MHC class II (RT1-B) }(1: 200) \\
\text { (structural marker for mature dendritic cells) }\end{array}$ & $\begin{array}{l}\text { GeneTex, cat\# } \\
\text { GTX76190, USA }\end{array}$ \\
\hline$c x-43$ & $\begin{array}{l}\text { goat polyclonal anti-connexin } 43 \text { (1:500) (gap junctions } \\
\text { marker) }\end{array}$ & $\begin{array}{l}\text { Santa Cruz Biotech cat\# } \\
\text { sc-6560, UK }\end{array}$ \\
\hline nos1 & $\begin{array}{l}\text { rabbit polyclonal anti-neuronal nitric oxide synthase } \\
\text { enzyme-1 (1:500) (functional marker, cell signalling } \\
\text { mechanism) }\end{array}$ & $\begin{array}{l}\text { Santa Cruz Biotech, cat\# } \\
\text { sc- } 648 \text {, UK }\end{array}$ \\
\hline $\operatorname{cox} 1$ & $\begin{array}{l}\text { gout polyclonal anti- cyclooxygenase-1 (1:100) } \\
\text { (functional marker, cell signalling mechanism) }\end{array}$ & $\begin{array}{l}\text { Santa Cruz Biotech, cat\# } \\
\text { sc-1752, UK }\end{array}$ \\
\hline $\begin{array}{l}\text { NaK- } \\
\text { ATPase }\end{array}$ & $\begin{array}{l}\text { rabbit monoclonal anti-sodium potassium-ATPase enzyme } \\
(1: 500) \text { (functional marker, ion transporter). }\end{array}$ & $\begin{array}{l}\text { Abcam cat\# Ab76020, } \\
\text { UK }\end{array}$ \\
\hline NHE1 & $\begin{array}{l}\text { rabbit polyclonal anti-sodium hydrogen exchanger-1 } \\
\text { (1:500) (functional marker, ion transporter). }\end{array}$ & $\begin{array}{l}\text { Santa Cruz Biotech, cat\# } \\
\text { sc-28758, UK }\end{array}$ \\
\hline NCX & $\begin{array}{l}\text { rabbit polyclonal anti-sodium calcium exchanger-1 } \\
\text { (1:500) (functional marker, ion transporter). }\end{array}$ & $\begin{array}{l}\text { Santa Cruz Biotech, cat\# } \\
\text { sc32881, UK }\end{array}$ \\
\hline
\end{tabular}



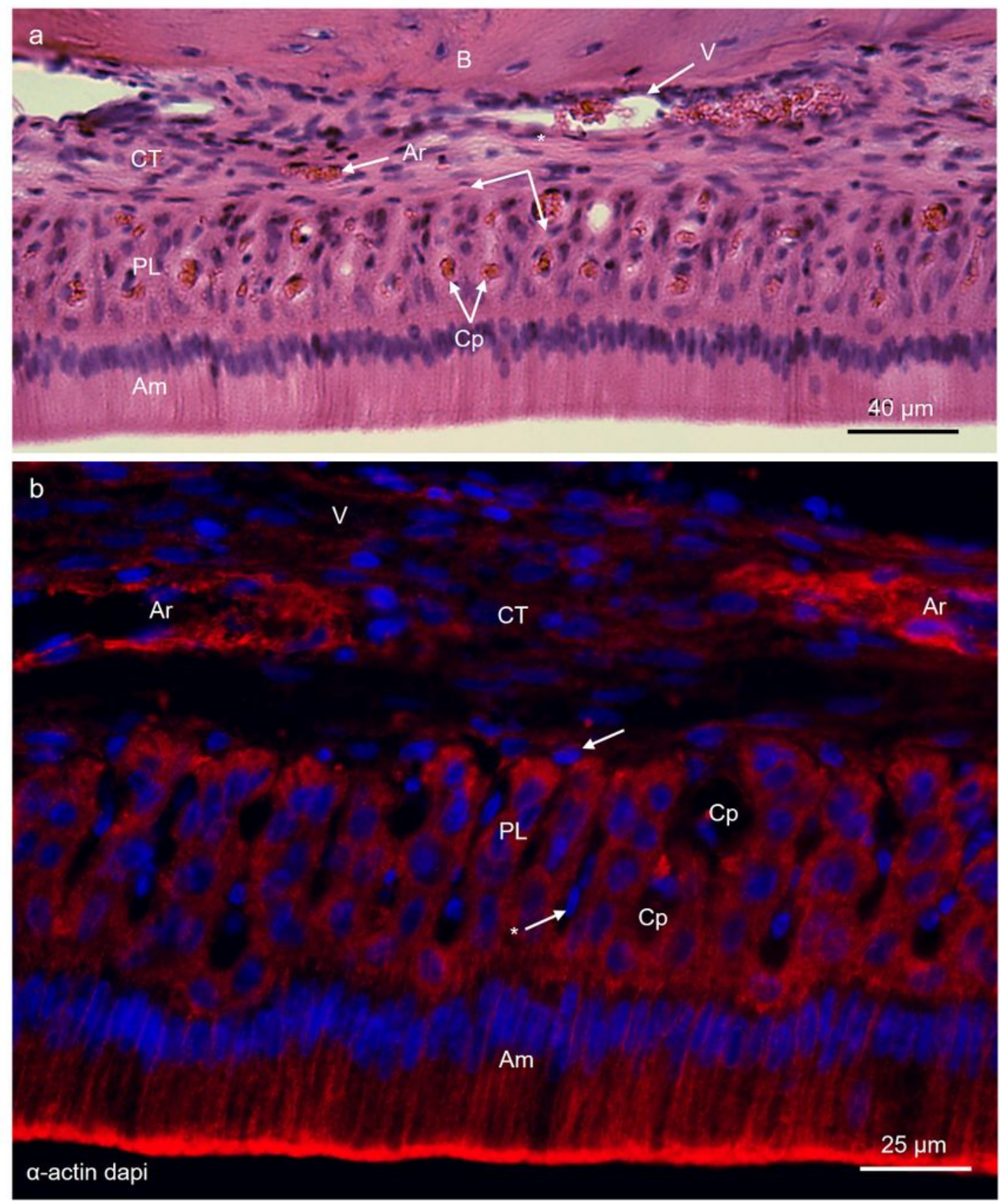

\section{Figure 1}

Sagittal sections of the enamel organ in the maturation stage of the rat mandibular incisor stained for haematoxylin and eosin (H\&E) panel (a) and a-smooth muscle actin (a-actin) panel (b). In (a), different structures of enamel organ can be identified: ameloblast cells (Am), papillary layer (PL), connective tissue 
(CT), capillaries (Cp) invaginated deeply between ridges of the papillary cells, arteriole (Ar), and flattened venule $(\mathrm{V})$ close the alveolar bone $\left.{ }^{(}\right)$. Similar section is shown in (b) identifying a-actin immuno-reactivity within Am and PL cells in addition to the walls of the arterioles (Ar) within connective tissue (CT). No aactin immuno-labelling has been identify within the connective tissue cells which found interstitially $\left(^{*}\right)$ or above papillary ridges (arrow)
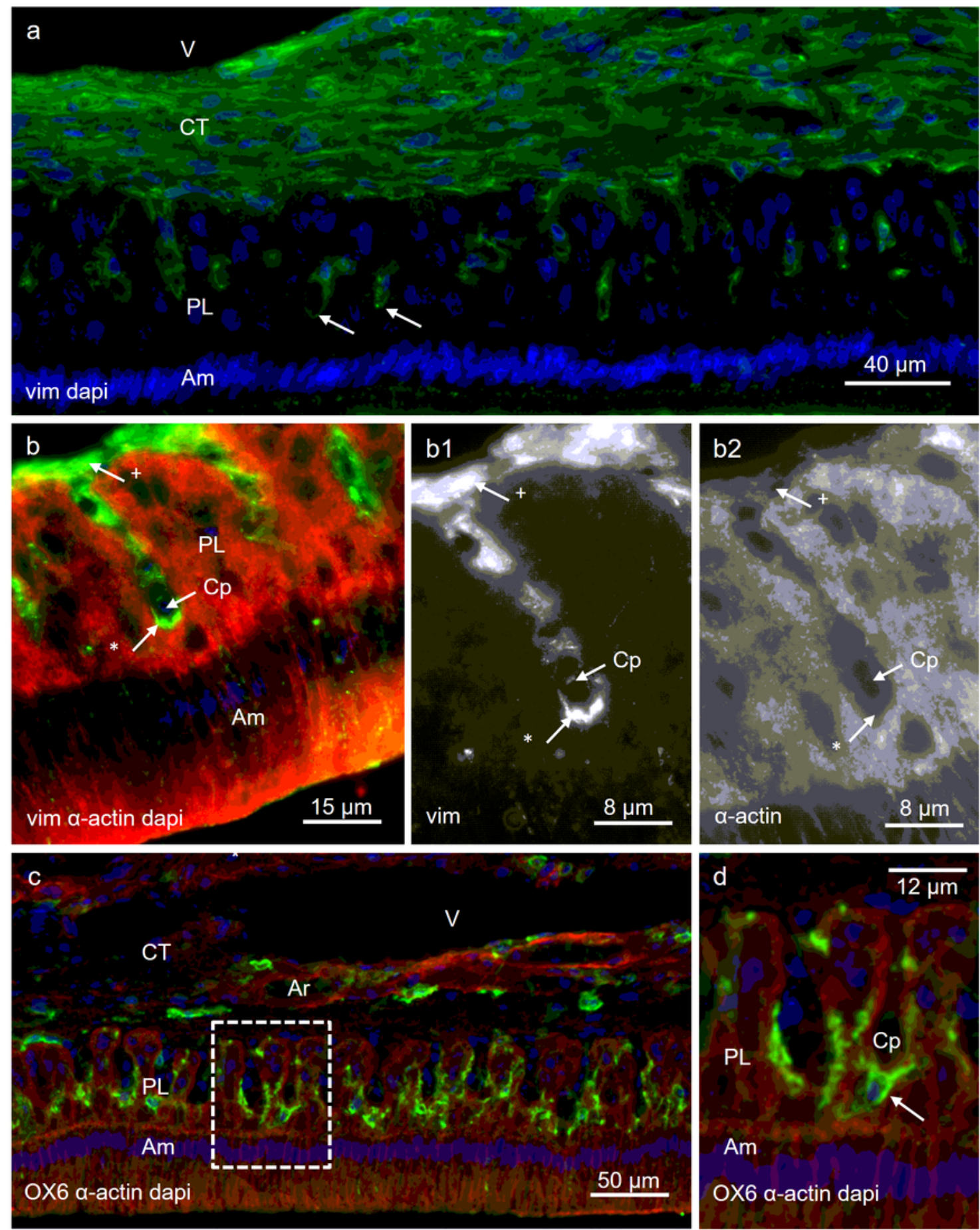

Figure 2 
Demineralized sagital section of rat mandibular incisor stained for different immunohistochemistry structural antibodies. (a) stained for vimintin (vim) in green and nuclei stain (dapi) in blue. This image shows vim immuno-reactivity within connective tissue (CT) cells and the intersitial cells between paillary ridges. No vim immuno-reactivity is found in the ameloblast (Am) or the papillary cells (PL). (b) is composite image stained for vim in green, a-actin in red and nuclei stain (dapi) in blue to show vim immuno-reactivity $\left(^{\star}\right)$ within interstitial connective tissue cells surrounding capillaries (Cp), and above the papillary ridges (+). Similar details are also clear in the component images (c1) and (c2) which stained for vim and a-actin respectively. Panel (c) stained for dendritic cell marker (OX6) in green, a-actin in red and nuclei stain dapi in blue. This section shows heavily distribution of dendritic cells ${ }^{*}$ ) within papillary layer $(\mathrm{PL})$ surrounding the capillaries invagination, in addition to scattered OX-6 immuno-labelling cells between papillary ridges and arterioles. The region of interest in (c) (dotted box) is illustrated at higher magnification in (d) to show the position of the dendritic cell (arrow) within the papillary layer surrounding a capillary (Cp) 


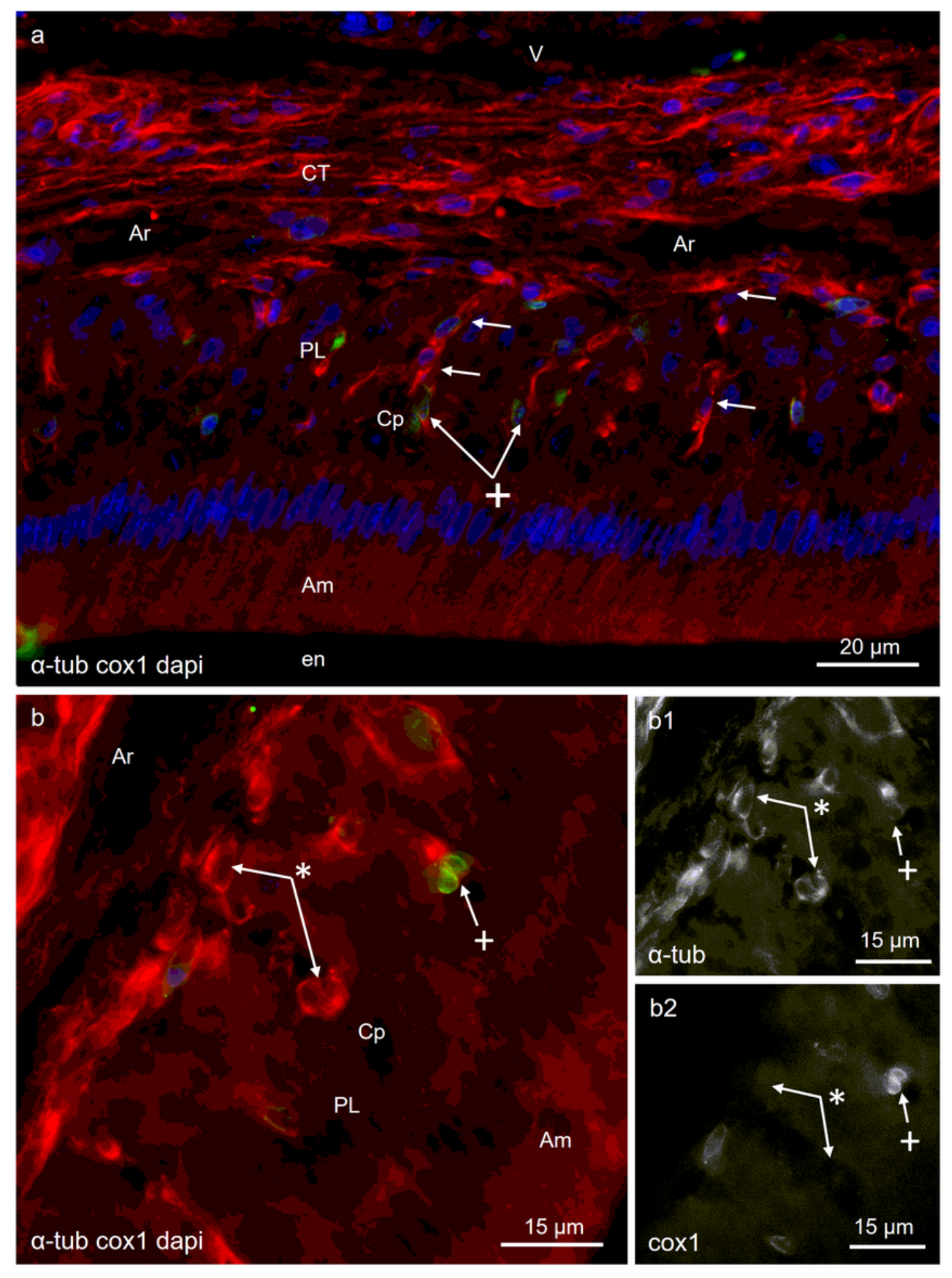

\section{Figure 3}

Sagittal sections of the rat mandibular incisor showing the enamel organ connective tissue in the maturation stage. (a) and (b) were stained for a-tubulin (a-tub) in red, cyclooxygenase-1 (cox1) in green and dapi in blue, while (b1) and (b2) are component images for (b) stained for a-tub and cox respectively. (a) is an overview image showing the deep capillaries (Cp) laying among the papillary layer (PL) ridges, arterioles (Ar) within the intermediate connective tissue (CT), and the venules (V) within the outer 
connective tissue. There are cells (arrows) descending from the inner CT interstitially between capillaries and papillary ridges. Some of these cells showing cox immuno-reactivity. Similar observations but with higher magnification are illustrated in (b) and its component images (b1) and (b2). These panels show the interstitial cells located near capillaries (Cp), and are immune-labelled to both cox-1 (+) and a-tub or to a-tub (*) only
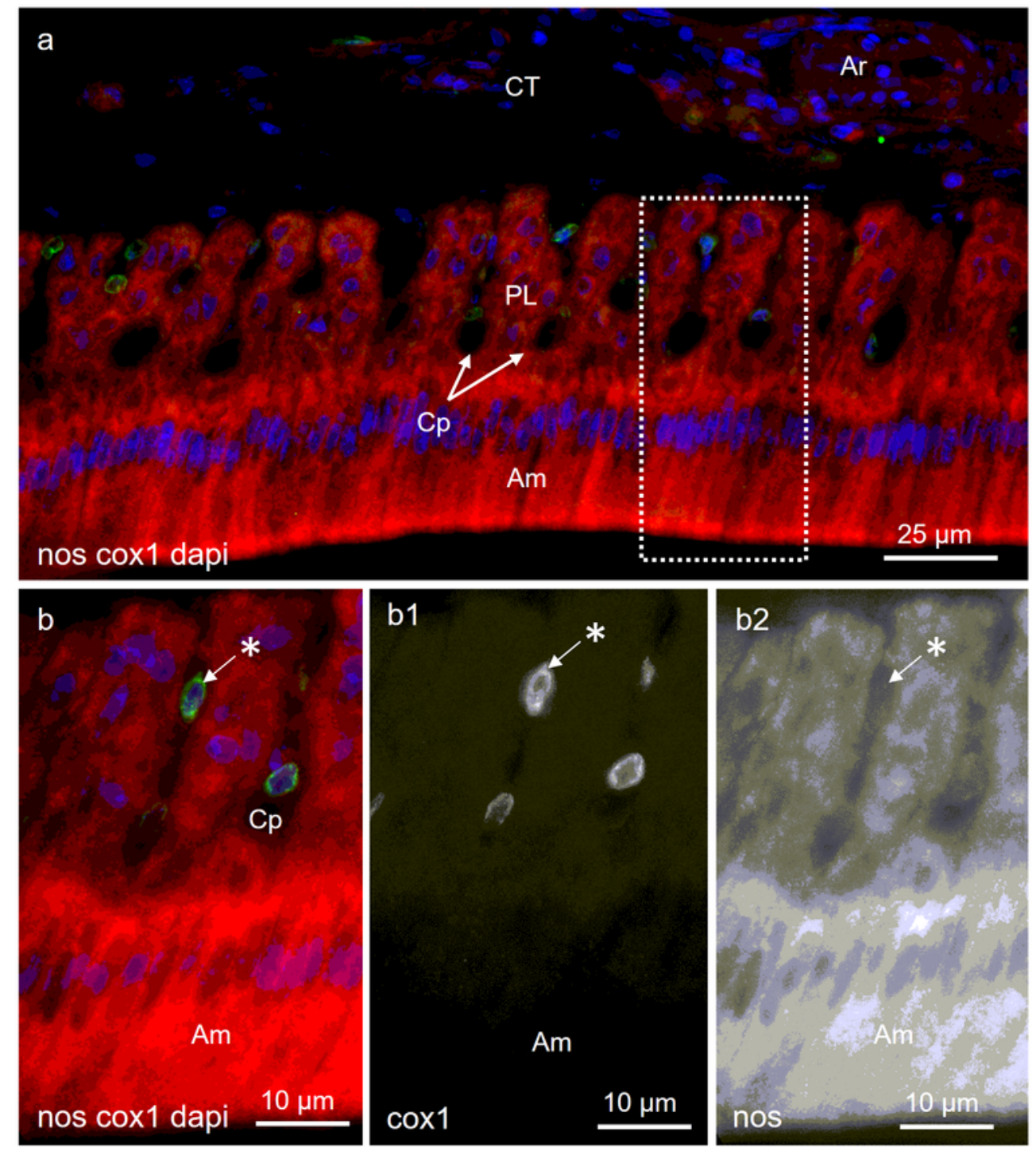

Figure 4 
Expression of nitric oxide (nos) and cyclooxygenase-1 (cox1) within sagittal sections of the rat mandibular incisor enamel organ during maturation stage. (a) and (b) was stained for nos in red, cox 1 in green and dapi in blue, and (b1) and (b2) are component images of (b) stained for cox1 and nos respectively. In A high intensity of nos immuno-reactivity is observed within ameloblasts (Am) and less in papillary layer (PL) and the least within arterioles (Ar). A highlighted region in (a) is illustrated at higher magnification in (b) and its component images (b1) and (b2). These images show cells within the interstitial CT close to capillaries (Cp) are immuno-labelled to cox, while other papillary layer cells and ameloblasts are immuno-reactive to nos 

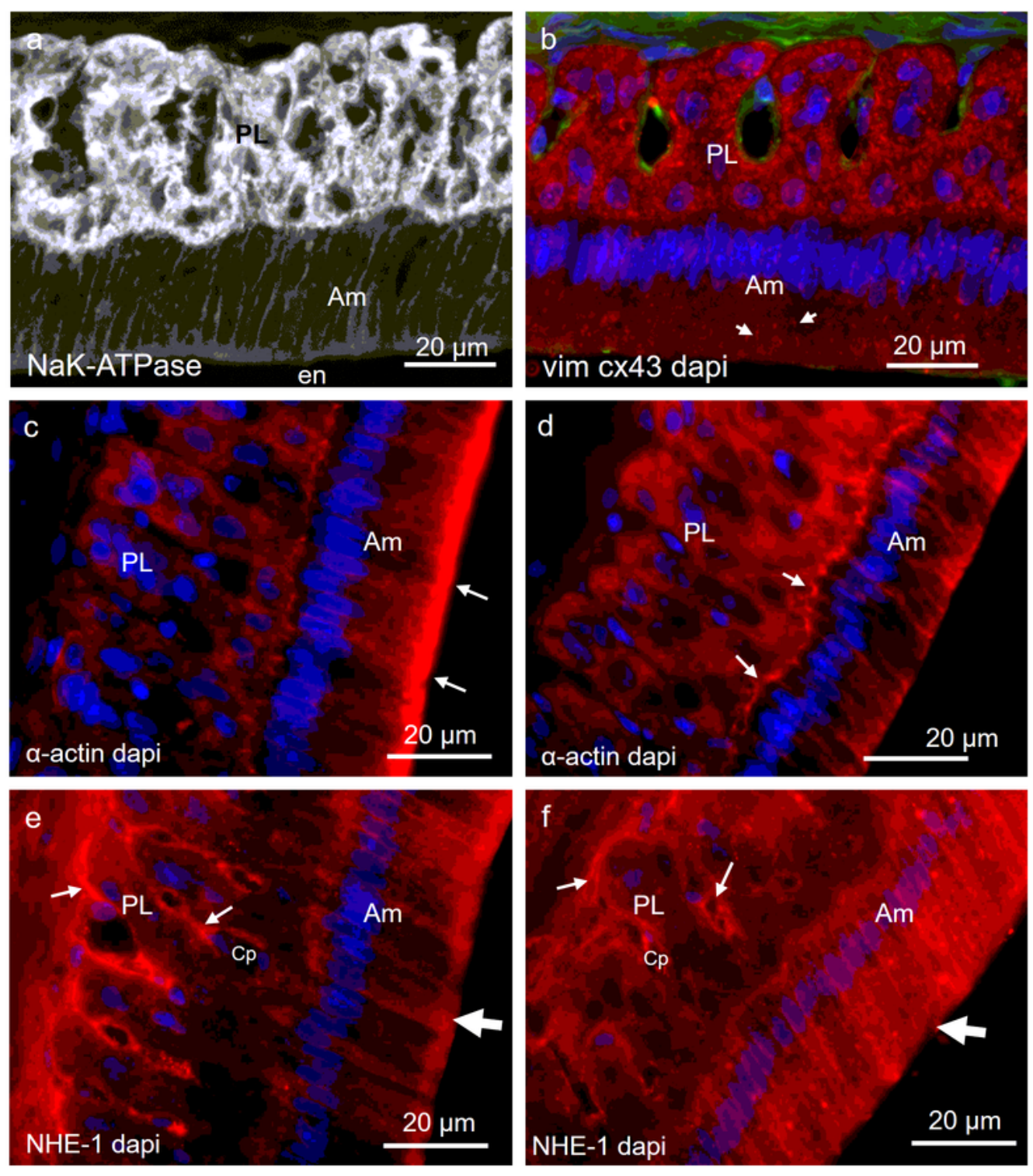

\section{Figure 5}

Sagittal sections of the enamel organ of the rat mandibular incisor stained for different antibodies during the maturation stage. (a) was stained for NaK-ATPase presented with high expression within papillary layer. The composite image (b) was stained for vimentin (vim) in green, connexion-43 (cx43) in red and dapi in blue. The immunolocalization of cx43 appear as punctuated or granular appearance which are highly presented within papillary layer and less on the lateral walls between ameloblasts (arrows). The 
changes in ameloblast cells between ruffled and smooth border are represented in images (c, e) and (d, f) respectively. Images (c) and (d) were stained for a-actin in red and dapi in blue. The differences in immunoreactivity of a-actin is clearly presented in the distal membrane (arrows) of the ruffle-ended ameloblasts in (c), while in the basal membrane (arrows) of smooth-ended ameloblasts in (d). Images (e, f) were stained for sodium-hydrogen exchanger (NHE-1) in red and dapi in blue. Both images show immuno-labelling of NHE-1 within interstitial cells of CT near capillaries (Cp) and above papillary layer $(\mathrm{PL})$ (arrows), in the distal border of ruffled ameloblasts (Am) (thick arrow in image 2), and within lateral membranes of smooth-ended Am (thick arrow in $\mathrm{f}$ ) 

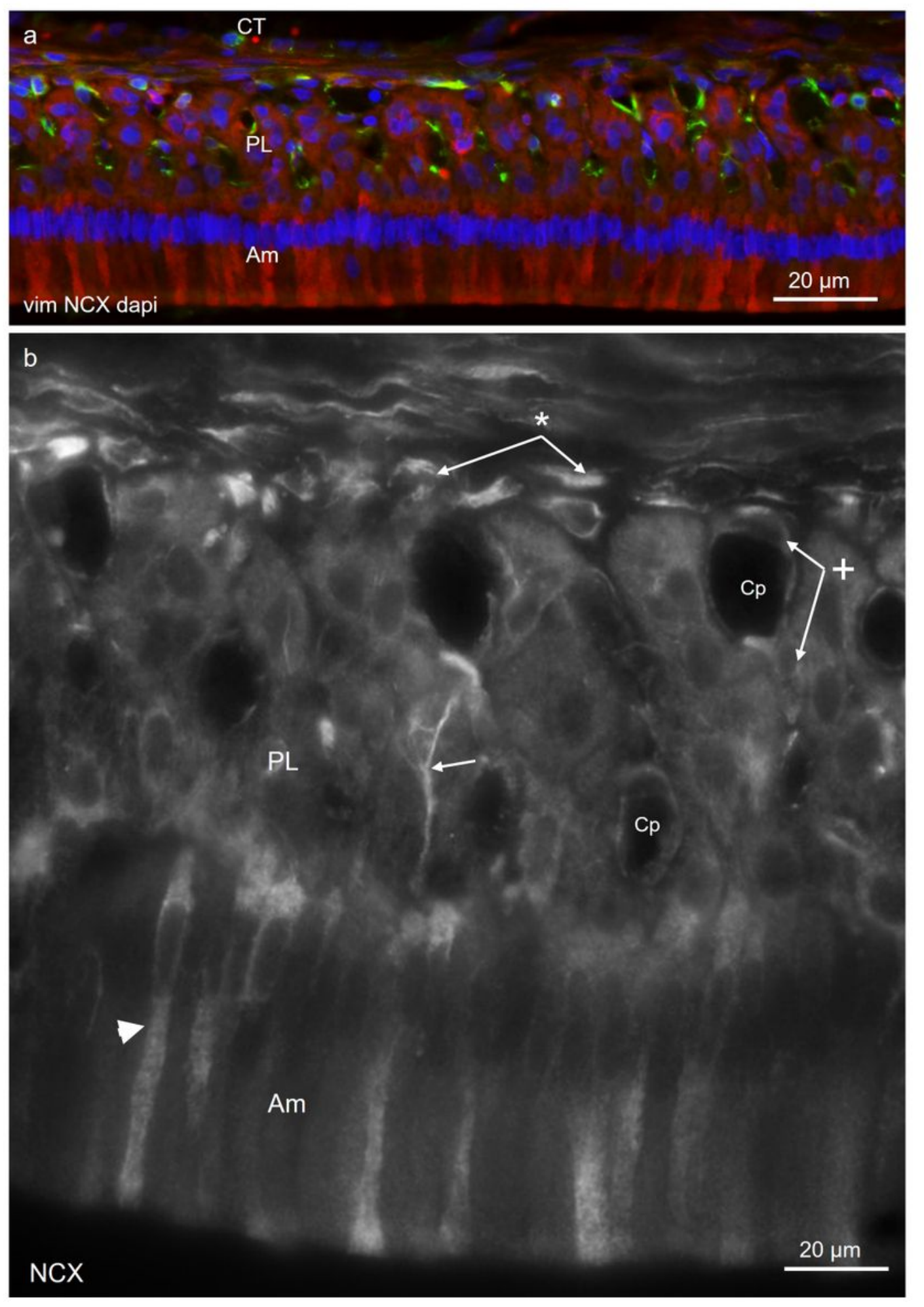

\section{Figure 6}

Sagittal sections of the enamel organ of the rat mandibular incisor showing the expression of sodium calcium exchanger (NCX) during the maturation stage. (a) stained for vim in green, NCX in red and dapi in blue, while (b) only stained for NCX. In (a) the expression of NCX appears within the epithelial cells of enamel organ (Am and PL) and the connective tissue cells above PL. At higher magnification (b) the higher expression of NCX is illustrated within some of the ameloblasts (Am) (arrow head), dendritic cell 
(arrow) within PL, and the connective tissue cells (*) above PL. Less intensity of NCX staining is identified within PL cells and the interstitial cells $(+)$ surrounding capillaries (Cp)

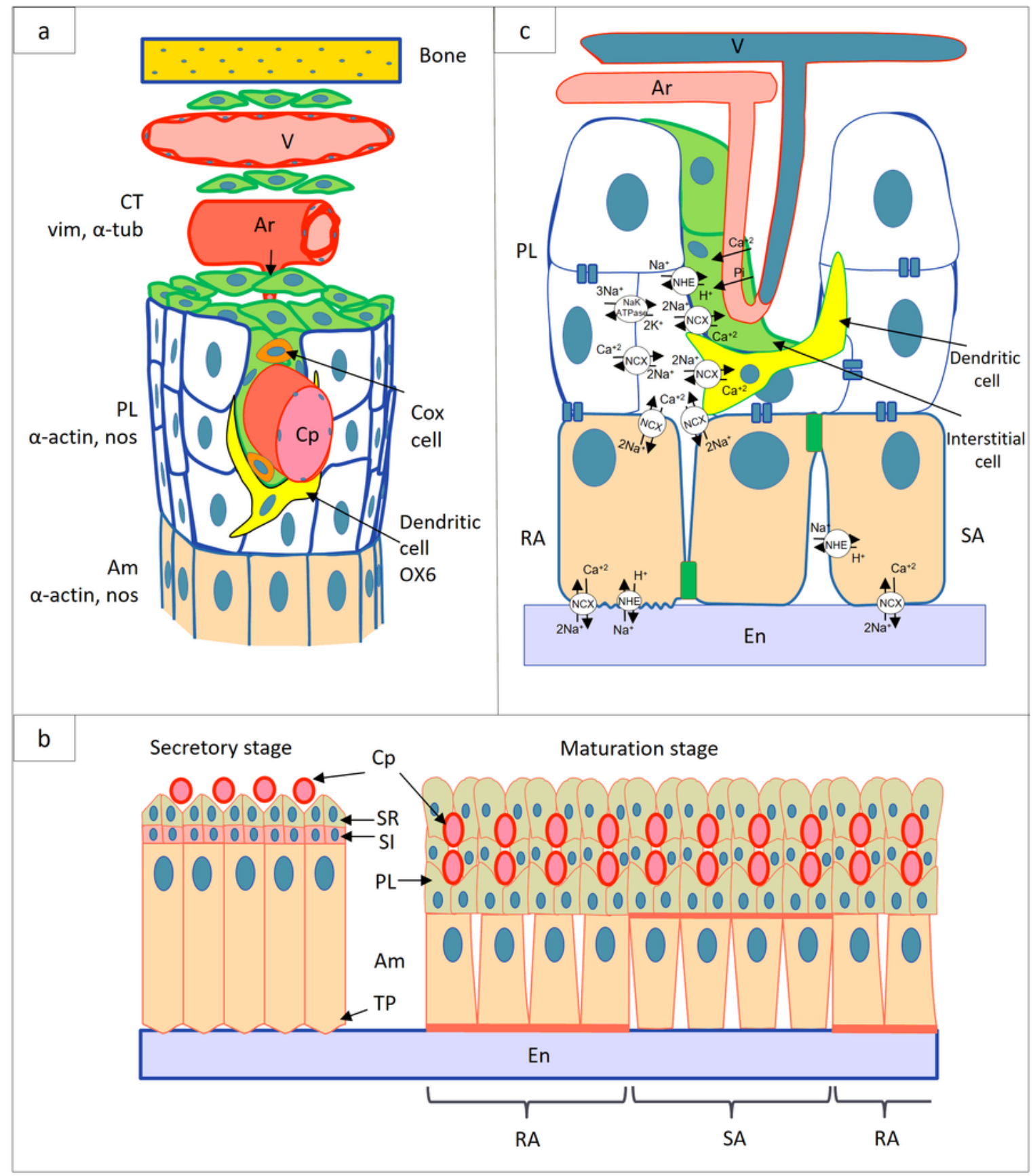

Figure 7

Schematic representation of the enamel organ cells. (a) represents a three dimension illustration of the epithelial and connective tissue regions with their microvasculature bed of the enamel organ. (b) shows morphological cellular changes between secretory and maturation stages of the epithelial portion of 
enamel organ. (c) illustrates the ion transportation during maturation stage. The following structures have been shown: Ameloblats (Am), papillary layer (PL), connective tissue cells (CT), arteriole (Ar), vein $(V)$, capillary (Cp), enamel (En), tomes' process (TP), ruffle-ended ameloblasts (RA), smooth-ended ameloblasts (SA), stratum intermedium (SI), and stellate reticulum (SR) 